\title{
Brief overview of meningitis in the Pacific Islands, and implications for public health, clinical, and rehabilitation services: A call to action
}

Annette $\operatorname{Kaspar}^{1,2}$, Sione Pifeleti ${ }^{1}$

${ }^{1}$ ENT Department, Tupua Tamasese Meaole Hospital, Ministry of Health, Apia, Samoa

${ }^{2}$ Hearing Research Unit for Children, School of Health and Rehabilitation Sciences, University of Queensland, Brisbane, Australia

Meningitis is well-known cause of permanent physical, hearing, and visual impairment among survivors.
$\mathrm{M}$ eningitis is a life-threatening inflammation of the membranes covering the brain and spinal cord [1] It is usually caused by bacterial and viral pathogens, and is more commonly found among children experiencing malnutrition, overcrowded households, and low levels of immunization [1]. Patients who survive meningitis infection are at risk of developing permanent disabilities, including physical, hearing, and visual impairments [2]. In Low and Middle Income Countries, improvements in public health, and the expansion of clinical and rehabilitation services for people with disabilities should reduce the burden of meningitis disease and its associated impairments. While the research appropriately focuses on improving immunization programs to prevent meningitis, there is little attention given to people currently living with the consequences of the infection. The World Health Organization highlighted the importance of improving diagnostic and rehabilitation services by including 'Support and Care for people affected by meningitis' as the fourth of five pillars in their 'Defeating Meningitis Roadmap' [3].

There is very little in the research literature on meningitis in the Pacific Islands. Encouragingly, the most recent report from the Global Burden of Disease Study found that the incidence, deaths, and Disability-Adjusted Life Years (DALYs) for meningitis in the Pacific Islands are in decline [1]. This may be attributed to improvements in routine childhood immunization programmes under the Millennium Development Goal Project (2000-2015), which targeted the meningitis bacterial pathogens Haemophilus influenzae Type b, Streptococcus pneumoniae, and Neisseria meningitidis (Table 1). However, meningitis is still a cause of death and disability in regions where immunization coverage is below optimal levels (Table 1).

A recent paper published in this journal called attention to the role of otorhinolaryngology and ophthalmology services in the aftermath of the measles epidemic in the Pacific Islands [5]. The aim of this brief perspective is to similarly highlight meningitis and the implications for public health and clinical services in the Pacific Islands. In parallel to improved immunization coverage to reduce the rate of meningitis among children, the development of essential clinical and rehabilitations services for meningitis survivors is advocated.

\section{OVERVIEW OF THE LITERATURE ON MENINGITIS IN THE PACIFIC ISLANDS}

There is very little in the research literature on the epidemiology of meningitis in the Pacific Islands. A recent hospital-based study from Fiji found that Streptococcus pneumoniae (55\%) was the most common bacterial pathogen for meningitis among children in the 0-5 age group, followed by Neisseria meningitidis (15\%) and Haemophilus influenzae type b (10\%) [6]. The study reported a case fatality rate of 36\% for meningitis caused 
Table 1. Availability of immunizations against meningitis, and coverage rate for immunizations including the Haemophilus influenzae type B vaccine in the Pacific Islands [4]

\begin{tabular}{|c|c|c|c|c|c|c|}
\hline \multirow[t]{2}{*}{ COUNTRY } & \multicolumn{3}{|c|}{ MENINGITIS PATHOGEN } & \multicolumn{3}{|c|}{ HIB VACCINE DELIVERY AND COVERAGE RATE } \\
\hline & $\begin{array}{c}\text { Neisseria } \\
\text { meningitidis }\end{array}$ & $\begin{array}{l}\text { Streptococcus } \\
\text { pneumoniae }\end{array}$ & $\begin{array}{c}\text { Haemophilus } \\
\text { influenzae type B }\end{array}$ & $\begin{array}{c}\text { Hib } \\
\text { vaccine }\end{array}$ & $\begin{array}{c}1^{\text {st }} \text { dose } \\
\text { coverage rate }(\%)\end{array}$ & $\begin{array}{c}3^{\text {rd }} \text { dose } \\
\text { coverage rate (\%) }\end{array}$ \\
\hline Cook Islands & & & Yes & DTaPHibHepB & 99 & 99 \\
\hline Fiji & & Yes & Yes & DTwPHibHepB & 99 & 99 \\
\hline Kiribati & & Yes & Yes & DTwPHibHepB & 98 & 95 \\
\hline Marshall Islands & Yes & Yes & Yes & DTaPHibIPV & 97 & 81 \\
\hline Micronesia & & Yes & Yes & $\mathrm{Hib}$ & - & 59 \\
\hline Nauru & & & Yes & DTwPHibHepB & 99 & 90 \\
\hline Niue & & Yes & Yes & $\mathrm{Hib}$ & - & 99 \\
\hline Palau & & Yes & Yes & $\mathrm{Hib}$ & - & 92 \\
\hline Papua New Guinea & & Yes & Yes & DTwPHibHepB & 67 & 61 \\
\hline Samoa & & & Yes & DTwPHibHepB & 56 & 34 \\
\hline Solomon Islands & & Yes & Yes & DTwPHibHepB & 86 & 85 \\
\hline Tonga & & & Yes & DTwPHibHepB & 86 & 81 \\
\hline Tuvalu & & & Yes & DTwPHibHepB & 99 & 89 \\
\hline Vanuatu & & & Yes & DTwPHibHepB & 93 & 85 \\
\hline
\end{tabular}

DTaPHibHepB - diphtheria and tetanus and pertussis and Haemophilus influenzae type B and hepatitis B vaccine, DTwPHibHepB - pentavalent diphtheria and tetanus toxoid with pertussis, Haemophilus influenzae type B and hepatitis B vaccine vaccine, DTaPHibIPV - diphtheria and tetanus toxoid with acellular pertussis, Haemophilus influenzae type B and inactivated polio (IPV) vaccine

by Streptococcus pneumoniae. There was an outbreak of enterovirus at the time of the Fijian study, and this viral pathogen was reported as the most common cause of meningitis during the data collection time frame.

Implementation of public health, clinical, and rehabilitation services are recommended for the prevention and management of meningitis in the Pacific Islands.
Another hospital-based study from Papua New Guinea investigated causal pathogens for suspected cases of meningitis among 1884 children between 1996 and 2005 [7]. Identifiable pathogens were isolated for 375 children only (19.9\%), and revealed Streptococcus pneumoniae $(\mathrm{n}=180)$ and Haemophilus influenzae $(\mathrm{n}=153)$ as the leading causal microbial agents. This pattern, and their serotypes described in the study, may have altered since the introduction of the current immunization schedules.

A recent review of meningococcal disease in the Asia-Pacific region is available, however, the Pacific Islands were not represented in this study [8]. Information on the prevalence of Neisseria meningitidis would be beneficial for evidence-based decision-making regarding the introduction of immunization against this pathogen into routine immunization schedules in the Pacific Islands.

\section{OVERVIEW OF THE LITERATURE ON THE NEUROLOGICAL SEQUELAE OF MENINGITIS IN THE PACIFIC ISLANDS}

A review of the literature found five papers addressing the leading neurological sequelae of meningitis among survivors in the Pacific Islands. There were four papers describing hearing impairment, with two of the papers

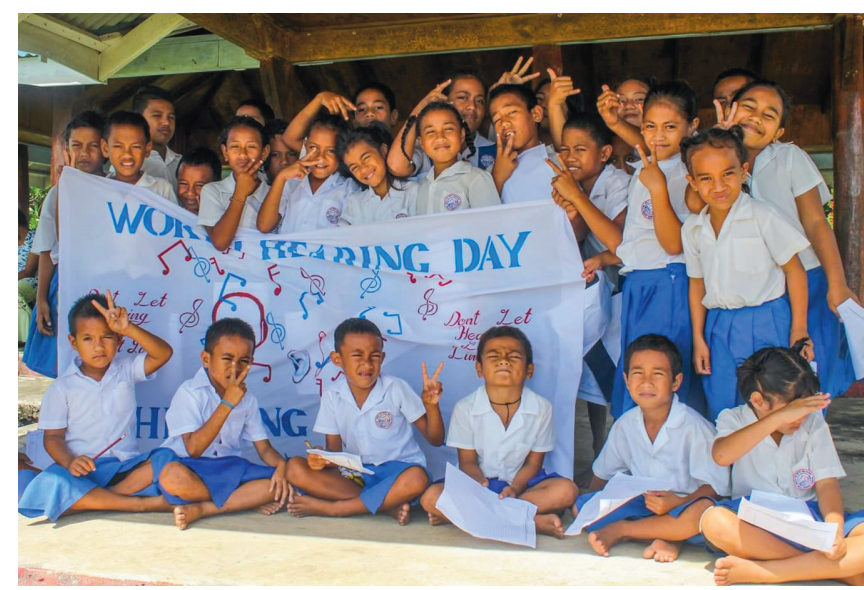

Photo: From the author's own collection, used with permission. published in the early 1990s $[9,10]$, and the more recent publications were limited by sample size and lack of formal audiometry testing $[6,11]$. The early paper from Vanuatu reported a permanent hearing impairment rate of $32.3 \%$ among meningitis survivors, and it continues to be the most cited paper on meningitis in the Pacific Islands in the audiology literature. A common theme throughout the four papers retrieved, however, is that routine ear and hearing assessments should be performed for all meningitis survivors.

The fifth paper addressed physical disability and associated mobility challenges among meningitis survivors in Papua New Guinea [12]. The authors strongly advocated for improved clinical and rehabilitation services for meningitis survivors with physical and mobility difficulties, especially among people with disabilities living in rural and remote 
parts of the country. The authors also described physiotherapy as a young profession in Papua New Guinea, and called for greater education of Community-Based Rehabilitation Workers to meet the needs of the population majority living outside urban settings.

Visual impairment is another well-known neurological sequelae of bacterial meningitis. The present review did not find any papers describing visual disability among meningitis survivors in the Pacific Islands.

\section{IMPLICATIONS FOR PUBLIC HEALTH, CLINICAL AND REHABILITATION SERVICES IN THE PACIFIC ISLANDS}

The table above indicates that there is an opportunity to strengthen routine childhood immunizations against the leading causal bacterial pathogens of meningitis in the Pacific Islands. Ideally, immunization should be available in all Pacific Island countries against the main bacterial pathogens of meningitis fatalities (Neisseria meningitidis) and meningitis-related disabilities (Streptococcus pneumoniae). At this time, all Pacific Islands include the Haemophilus influenzae vaccine in their immunization schedules, eight out of fourteen countries include the Streptococcus pneumoniae vaccine, and only the Marshall Islands offer the Neisseria meningitidis vaccine.

The barriers preventing optimal immunization coverage rates should also be addressed. The table indicates that the most recent coverage rate data was lowest for Samoa, and this is most likely related to the urgent recall of vaccines and necessary suspension of the National Immunization Program. The second lowest coverage rate is for Papua New Guinea, the largest archipelago of the Pacific Island countries, and therefore the nation with the greatest challenge of accessing all rural and remote areas for optimal immunization program delivery. This is an opportunity for cross-sector collaboration under the Sustainable Development Goals, where improved transport and infrastructure will also benefit health outcomes.

As advocated for the case of measles in the Pacific Islands, health promotion activities regarding meningitis in this region should highlight that routine childhood immunizations not only save lives, but also prevent the risk of life-long disabilities. The neurological sequelae of meningitis are well-known from the global literature. The Sustainable Development Goal Agenda offers an excellent platform to establish or strengthen clinical and rehabilitation services for meningitis survivors living with physical, hearing, and/or visual impairments. Among young children in particular, routine ear/hearing and eye/vision assessment is recommended because mild or moderate degrees of impairment may often be overlooked. Where specialized health professions are scarce or non-existent, the World Health Organization promotes Community-Based Rehabilitationists for the care of children and adults with disabilities.

\section{CONCLUSION}

Although there is little in the research literature regarding meningitis and associated sequelae in the Pacific Islands, this should not deter efforts to strengthen current childhood immunization schedules, improve coverage rates, and include the leading causal meningitis pathogens of death and disability in the programme. Routine ear/hearing and eye/vision assessments for all meningitis survivors is also vital to ensure early identification of any sensory impairment, and facilitate early intervention options as required. Improved rehabilitation services for people with physical disabilities is also essential. As clinical and rehabilitation services are strengthened in urban settings, a regular outreach programme to rural/remote settings is strongly advocated.

\section{Funding: None.}

Authorship contributions: AK wrote the initial draft manuscript, and SP provided revisions and feedback.

Competing interests: The authors completed the ICMJE Unified Competing Interest form (available upon request from the corresponding author) and declare no conflicts of interest. 
1 GBD 2016 Meningitis Collaborators. Global, regional, and national burden of meningitis, 1990-2016: a systematic analysis for the Global Burden of Disease Study 2016. Lancet Neurol. 2018;17:1061-82. Medline:30507391 doi:10.1016/S14744422(18)30387-9

2 Edmond K, Clark A, Korczak VS, Sanderson C, Griffiths UK, Rudan I. Global and regional risk of disabling sequelae from bacterial meningitis: a systematic review and meta-analysis. Lancet Infect Dis. 2010;10:317-28. Medline:20417414 doi:10.1016/ S1473-3099(10)70048-7

3 WHO. Defeating meningitis by 2030 - developing a global roadmap. 2019.

4 WHO. Global Health Observatory. Available: http://apps.who.int/gho/data/node.main.A824?lang=en Accessed: 12 August 2020.

5 Kaspar A, Pifeleti S, Whitfield B. The measles emergency is over, but the crisis continues - a call to action for the Pacific Islands. J Glob Health. 2020;10:020301. Medline:33110505 doi:10.7189/jogh.10.020301

6 Biaukula VL, Tikoduadua L, Azzopardi K, Seduadua A, Temple B, Richmond P, et al. Meningitis in children in Fiji: etiology, epidemiology, and neurological sequelae. Int J Infect Dis. 2012;16:e289-95. Medline:22342257 doi:10.1016/j.jiid.2011.12.013

7 Greenhill AR, Phuanukoonnon S, Michael A, Yoannes M, Orami T, Smith H, et al. Streptococcus pneumoniae and Haemophilus influenzae in paediatric meningitis patients at Goroka General Hospital, Papua New Guinea: serotype distribution and antimicrobial susceptibility in the pre-vaccine era. BMC Infect Dis. 2015;15:485. Medline:26521138 doi:10.1186/s12879-0151197-0

8 Aye AMM, Bai X, Borrow R, Bory S, Carlos J, Caugant DA, et al. Meningococcal disease surveillance in the Asia-Pacific region (2020): the global meningococcal initiative. J Infect. 2020;81:698-711. Medline:32730999. doi:10.1016/j.jinf.2020.07.025

9 Carroll KJ, Carroll CA. Prospective investigation of the longterm auditory-neurological sequelae associated with bacterial meningitis: a study from Vanuatu. J Trop Med Hyg. 1994;97:145-50. Medline:8007054

10 Aithal V, Gupta AC, Vele D. Hearing loss in Papua New Guinea: a study of outpatients attending Port Moresby General Hospital. P N G Med J. 1995;38:36-44. Medline:8571676

11 Wandi F, Kiagi G, Duke T. Long-term outcomes for children with bacterial meningitis in rural Papua New Guinea. J Trop Pediatr. 2005;51:51-3. Medline:15601647 doi:10.1093/tropej/fmh075

12 Karthikeyan P, Ramalingam K. Meningitis: is a major cause of disability amongst Papua New Guinea children? Disabil Rehabil. 2012;34:1585-8. Medline:22256779 doi:10.3109/09638288.2011.651190

\section{Correspondence to:}

Dr Annette Kaspar

ENT Department

Tupua Tamasese Meaole Hospital

Ministry of Health

Apia, SAMOA

annette.kaspar@gmail.com 